\title{
Secretion of fructosyltransferase by Streptococcus salivarius involves the sucrose-dependent release of the cell-bound form
}

\author{
Carolyn P. Milward and Nicholas A. JaCQues* \\ Institute of Dental Research, United Dental Hospital of Sydney, Surry Hills, New South Wales 2010, Australia
}

(Received 18 August 1989; accepted 28 September 1989)

\begin{abstract}
Three strains of Streptococcus salivarius including a recent clinical isolate were found to possess $\mathrm{Ca}^{2+}$-dependent fructosyltransferase (FTF) activity. The extracellular FTF activity of cells grown on sucrose increased as much as 9-fold compared with cells grown on either glucose, fructose or galactose. This increase in activity was due not to induction of FTF by sucrose, but to the release of the cell-bound form of the enzyme. Studies with washed cells of $S$. salivarius ATCC 25975 showed that the extent of release of the cell-bound FTF activity was dependent upon the sucrose concentration up to $4 \mathrm{mM}$, at which concentration maximum release $(95 \%)$ of cell-bound FTF occurred. Several lines of evidence suggested that either substrate binding or de novo synthesis of fructan is required for the release of the cell-bound FTF activity.
\end{abstract}

\section{Introduction}

The fructosyltransferases (FTFs) of oral streptococci polymerize sucrose to form fructan molecules of $M_{\mathrm{r}}$ $20-100 \times 10^{6}$. These polymers act as extracellular storage compounds and are readily degraded by fructan hydrolases during periods of carbohydrate limitation (Walker \& Jacques, 1987). In Streptococcus salivarius ATCC 25975 the FTF activity is $\mathrm{Ca}^{2+}$-dependent (Jacques, 1984). Most (90-95\%) of this activity is bound to the cells when the bacteria are grown on glucose in batch culture (Jacques \& Wittenberger, 1981). The rate of expression of this cell-bound form correlates with the rate of incorporation of octadecenoic acid into the membrane lipids and the suggestion has been made that the enzyme may be synthesized and bound to the cytoplasmic membrane in a co-ordinated manner by means of a lipophilic anchor (Pitty \& Jacques, 1987). The rate of expression of cell-bound FTF may therefore vary some 350-fold depending upon the degree of saturation of the membrane lipids, implying that the lipid environment is one means by which the expression of this enzyme is regulated.

These observations leave a number of questions unanswered. For example, the source of the extracellular FTF activity of $S$. salivarius is unknown. Is it coded for by a separate gene or is it derived from the cell-bound form? Batch cultures grown in the presence of $500 \mathrm{~mm}$ -

Abbreviations: FTF, fructosyltransferase; GTF, glucosyltransferase; LTA, lipoteichoic acid. ethanol, for instance, show a $68 \%$ reduction in cellbound FTF activity, while the amount of extracellular activity remains unchanged (Markevics et al., 1987).

Bacillus subtilis also possesses an FTF enzyme (a levansucrase). In strain 168 Marburg this activity is not released into the culture medium, while in the hyperproducing $\left(\operatorname{sac} U^{\mathrm{h}}\right)$ derivative most of the activity is secreted. In both of these strains enzyme expression is induced by sucrose (Chambert \& Petit-Glatron, 1984). To the best of our knowledge, no similar investigation into the effect of sucrose on the expression of FTF has been carried out with strains of $S$. salivarius. We have therefore looked at the role sucrose plays in the expression of FTF in three strains of $S$. salivarius including a recent clinical isolate. Our investigations indicate that FTF expression is not induced by sucrose, but that sucrose regulates the secretion of the cell-bound form of the enzyme.

\section{Methods}

Bacterial strains and growth conditions. Three strains of Streptococcus salivarius were used in these studies. They were strain ATCC 25975, strain HB (kindly provided by Dr S. Hogg, University of Newcastle upon Tyne, UK) and a recent clinical isolate designated MW15 that had been subcultured to a minimum degree (kindly provided by Dr M. Willcox, Institute of Dental Research, NSW, Australia). Stock cultures were maintained at $-70^{\circ} \mathrm{C}$ in $40 \%(\mathrm{v} / \mathrm{v})$ glycerol.

The bacteria were grown at $37^{\circ} \mathrm{C}$ in semi-defined medium (Jacques, 1983) containing $1 \mathrm{~mm}-\mathrm{CaCl}_{2}$ and $1 \mathrm{~mm}$-histidine (to minimize FTF inactivation) unless otherwise indicated. Semi-aerobic batch cultures $(50 \mathrm{ml})$ were grown without shaking in $250 \mathrm{ml}$ screw-capped bottles. Growth was monitored with a Corning colorimeter model 252 using a $600 \mathrm{~nm}$ filter (EEL). 
Preparation of washed cell suspensions. As the cultures entered stationary phase they were harvested by centrifugation $\left(8000 \mathrm{~g}, 4{ }^{\circ} \mathrm{C}\right.$, $10 \mathrm{~min}$ ), washed and resuspended in $2.5 \mathrm{ml} 10 \mathrm{~mm}$-potassium phosphate buffer, $\mathrm{pH} 6 \cdot 5$, containing $10 \mathrm{~mm}-\mathrm{MgSO}_{4}$. Cells were stored on ice until used (within $10 \mathrm{~min}$ of harvesting), then equilibrated to $37^{\circ} \mathrm{C}$ for $2 \mathrm{~min}$ before addition to a pre-equilibrated suspension mixture. Cells were suspended to a concentration of $0 \cdot 80 \pm 0 \cdot 10 \mathrm{mg} \mathrm{dry} \mathrm{wt} \mathrm{ml}^{-1}$ in 5 or $10 \mathrm{ml}$ vols of suspension mixture containing $100 \mathrm{mM}$-potassium phosphate buffer, pH 6.5, $10 \mathrm{~mm}-\mathrm{NaF}, 1 \mathrm{~mm}$-histidine, $50 \mu \mathrm{g}$ chloramphenicol $\mathrm{ml}^{-1}, 1 \mathrm{~mm}-\mathrm{CaCl}_{2}$ (unless otherwise indicated) and a designated carbohydrate. Samples $(1 \mathrm{ml})$ were harvested rapidly in a microfuge $(30 \mathrm{~s})$ and $100 \mu \mathrm{l}$ of the supernatant placed on ice in the sucrose-free assay mix for periods of up to $2 \mathrm{~h}$ prior to assay.

Preparation of water-soluble fructan. FTF $\left(4 \cdot 4 \mathrm{U} \mathrm{I}^{-1}\right)$ that had been released from cells in the presence of $5 \mathrm{mM}$-sucrose was incubated for $48 \mathrm{~h}$ at $37^{\circ} \mathrm{C}$ in $10 \mathrm{~mm}$-potassium phosphate buffer, pH 6.5 , containing $120 \mathrm{~mm}$-sucrose, $1 \mathrm{~mm}$-histidine, $1 \mathrm{~mm}-\mathrm{CaCl}_{2}$ and $3 \mathrm{~mm}-\mathrm{NaN}_{3}$. The fructan synthesized was precipitated by the addition of 2 vols of ethanol and harvested by centrifugation $\left(20000 \mathrm{~g}, 4^{\circ} \mathrm{C}, 30 \mathrm{~min}\right)$. The fructan was redissolved in a minimum volume of water, insoluble material removed by centrifugation $\left(20000 \mathrm{~g}, 4^{\circ} \mathrm{C}, 30 \mathrm{~min}\right)$, and the soluble fructan reprecipitated as above. This procedure was repeated once more, the fructan washed twice in $75 \%(\mathrm{v} / \mathrm{v})$ ethanol and the final material freeze-dried.

Assay of enzyme activity. FTF and GTF activities were measured as previously described (Jacques, 1985). One unit of enzyme activity (U) was defined as the amount of FTF or GTF that catalysed the incorporation of $1 \mu \mathrm{mol}$ of the fructose or glucose moiety of sucrose respectively into $75 \%(\mathrm{v} / \mathrm{v})$ ethanol-insoluble polysaccharide $\mathrm{min}^{-1}$.

Where appropriate, results are presented as the mean \pm SD for all equivalent experiments. The number of these experiments is given by ' $n$ '.

\section{Results}

\section{Effect of sucrose on the expression of FTF activity in S. salivarius}

All three strains of $S$. salivarius possessed FTF activities that were $\mathrm{Ca}^{2+}$-dependent. Addition of $1 \mathrm{mM}^{-\mathrm{Ca}^{2+}}$ to washed cells, repeatedly subcultured through numerous generations in $\mathrm{Ca}^{2+}$-deficient medium (Jacques, 1984), stimulated FTF activity some 8-fold for strain ATCC 25975, 4-fold for strain HB and 17-fold for strain MW15.

The cell-bound and extracellular FTF activity of the three strains of $S$. salivarius grown in batch culture on a variety of carbohydrate sources was measured as the cells entered stationary phase. For any given strain no significant difference in the amount or distribution of FTF activity was observed when cells were grown on $25 \mathrm{~mm}$-galactose, $25 \mathrm{~mm}$-glucose or $25 \mathrm{~mm}$-fructose (data not shown). In contrast, the extracellular FTF activity of cells grown on $12.5 \mathrm{~mm}$-sucrose increased as much as 9-fold. However, for a given strain, the total (cellassociated plus extracellular) activity remained essentially the same (Table 1). Although Tween 80 $\left(0.05 \mu \mathrm{ml}^{-1}\right)$ promoted FTF expression in each strain to an extent that was in keeping with previous observations
(Pitty \& Jacques, 1987), the surfactant did not alter the percentage distribution of cell-associated or extracellular FTF activity. This was the case irrespective of whether cells were grown on glucose or sucrose (Table 1).

\section{Release of cell-bound FTF activity in washed cell suspensions}

The loss of cell-bound FTF activity observed in cultures of $S$. salivarius grown on sucrose was further examined in washed cell suspensions in which both glycolysis and protein synthesis were inhibited by the addition of $10 \mathrm{mM}-\mathrm{NaF}$ and $50 \mu \mathrm{g}$ chloramphenicol $\mathrm{ml}^{-1}$, respectively. In this system, sucrose but not glucose, fructose, galactose or soluble fructan, promoted the release of the cell-bound form of the enzyme (Table 2).

Table 1. Effect of carbohydrate source and added Tween 80 on the expression and distribution of FTF in $S$. salivarius

\begin{tabular}{lccc}
\hline & & \multicolumn{2}{c}{ Extracellular FTF activity* } \\
\cline { 3 - 4 } $\begin{array}{c}\text { Strain of } \\
\text { S. salivarius }\end{array}$ & $\begin{array}{c}\text { Tween } 80 \\
\left(0.05 \mu \mathrm{ml}^{-1}\right)\end{array}$ & Glucose-grown & Sucrose-grown \\
\hline ATCC 25975 & - & $10 \%(779)$ & $42 \%(799)$ \\
\multirow{2}{*}{ HB } & + & $16 \%(990)$ & $38 \%(884)$ \\
& - & $9 \%(176)$ & $70 \%(174)$ \\
MW15 & + & $8 \%(363)$ & $61 \%(277)$ \\
& - & $8 \%(262)$ & $53 \%(317)$ \\
& + & $5 \%(476)$ & $44 \%(436)$ \\
\hline \hline
\end{tabular}

* Numbers in parentheses are the total (cell-associated plus extracellular) FTF activity in mU (mg dry $w t)^{-1}$.

Table 2. Effect of carbohydrate source on the release of cell-bound FTF activity in washed cell suspension

Cells were incubated at $37^{\circ} \mathrm{C}$ for $60 \mathrm{~min}$, harvested and the cellbound and extracellular FTF activities determined. ND, Not determined.

\begin{tabular}{lccc}
\hline \multirow{2}{*}{$\begin{array}{c}\text { Carbohydrate } \\
\text { (concn) }\end{array}$} & \multicolumn{3}{l}{ Release of cell-bound FTF activity $(\%)$} \\
\cline { 2 - 4 } & ATCC 25975 & HB & MW 15 \\
\hline None & 4 & 3 & 11 \\
Galactose $(10 \mathrm{mM})$ & 4 & 0 & 10 \\
Glucose $(10 \mathrm{mM})$ & 4 & 5 & 11 \\
Fructose $(10 \mathrm{mM})$ & 4 & 2 & 13 \\
Soluble fructan & 4 & ND & ND \\
$\left(0 \cdot 1 \mathrm{mg} \mathrm{ml}^{-1}\right)$ & 4 & ND & ND \\
Soluble fructan & & & \\
$\left(1 \cdot 0 \mathrm{mg} \mathrm{ml}^{-1}\right)$ & 95 & 84 & 81 \\
Sucrose $(10 \mathrm{mM})$ & & & \\
\hline \hline
\end{tabular}


Kinetics of the release of FTF activity from $S$. salivarius ATCC 25975

Further examination of the release of FTF activity in the presence of sucrose was limited to studies with $S$. salivarius ATCC 25975.

The release of cell-bound FTF activity was monitored over a period of $60 \mathrm{~min}$ at $10 \mathrm{~min}$ intervals. No enzyme was released from cells at a sucrose concentration below $500 \mu \mathrm{M}$. At intermediate concentrations of sucrose up to $5 \mathrm{mM}$ the amount of cell-bound FTF activity released into the external milieu was dependent upon the sucrose concentration. The measured amount of released enzyme reached a maximum after approximately $10-20 \mathrm{~min}$ and then declined. The final level of activity stabilized at a level approximately $30 \%$ below the measured maximum (Fig. 1). This decrease in activity was due to the loss of measurable FTF activity during the first $30 \mathrm{~min}$ of incubation at $37^{\circ} \mathrm{C}$, for a similar decline in total activity was observed in cell suspensions irrespective of the presence (Fig. 1) or absence (data not shown) of sucrose. The extent of this loss of activity was unexpected in light of the precautions taken to prevent free radical inactivation of the enzyme by adding $\mathrm{Ca}^{2+}$ and histidine to the incubation mixture (Jacques \& Wittenberger, 1981; Abbe et al., 1986). The formation of fructan and hence product inhibition was ruled out as a cause of this loss of

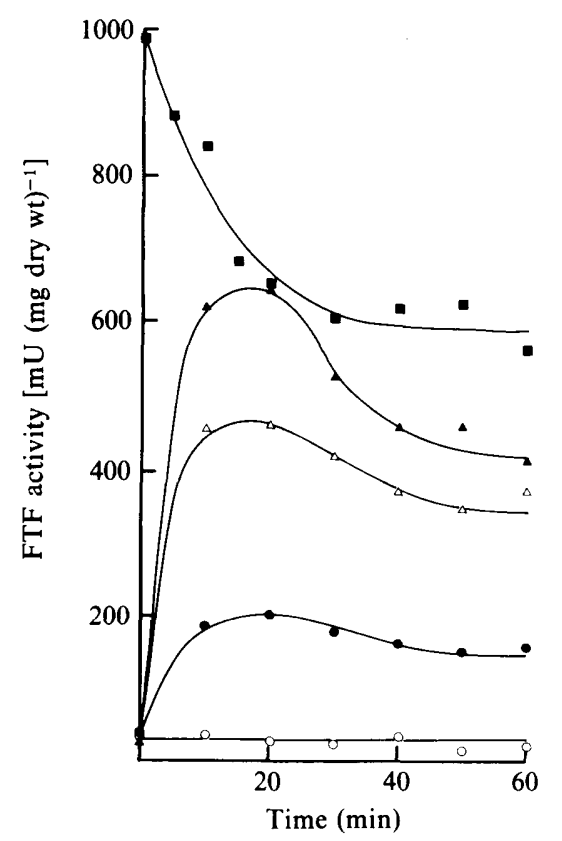

Fig. 1. Measurable extracellular FTF activity following the release of the enzyme from washed cells of $S$. salivarius ATCC 25975 at sucrose concentrations of $500 \mu \mathrm{M}(O), 1 \mathrm{~mm}(\bigcirc), 3 \mathrm{~mm}(\triangle)$ and $5 \mathrm{~mm}(\Delta)$ compared with the loss of total (cell-bound plus extracellular) activity from cells incubated with $5 \mathrm{~mm}$ sucrose (a). measurable activity. Two lines of reasoning supported this conclusion. First, the addition of up to $2 \mathrm{mg}$ soluble fructan $\mathrm{ml}^{-1}$ to the cell suspensions did not alter the kinetics or the amount of measurable FTF activity released with time (data not shown). Secondly, if fructan synthesis was inhibitory, then the rate of fructan formation would not be expected to be linear with time as previously reported (Jacques \& Wittenberger, 1981), and rigorously confirmed $(n=7)$ at 1 min intervals during the course of the present investigation.

The peak of measured extracellular activity was sometimes greater than the total measured (cell-bound plus extracellular) activity (5 out of 10 experiments; cf. Figs 2 and 3). No evidence was obtained to indicate that the secreted enzyme was more active than its bound form, and the observation was put down to an error in sampling and subsequently measuring the FTF activity of the control cells as they underwent their loss in activity with time (cf. Fig. 1). It should also be noted that by the very nature of the assay the cell-bound FTF is being released from the cells during the course of its measurement.

\section{Factors affecting the release of FTF activity from S. salivarius ATCC 25975}

Several methods similar to those applied previously to inactivate the cell-associated FTF degradation factor, such as incubation in low ionic strength and low $\mathrm{pH}$ buffers (Jacques \& Wittenberger, 1981), were used in an

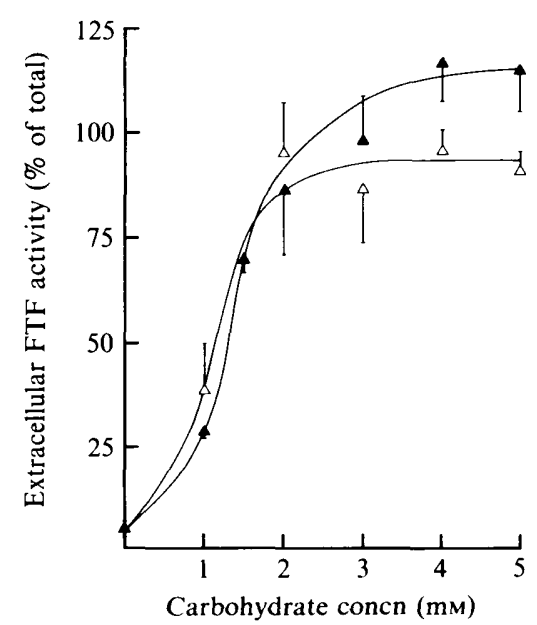

Fig. 2. Dependence of cell-associated FTF release on the concentration of enzyme substrate. The data compare the extracellular FTF activity of $S$. salivarius ATCC 25975 with the total measurable (cellbound plus extracellular) activity after $20 \mathrm{~min}$ incubation in the presence of various concentrations of sucrose $(\boldsymbol{A})$ or raffinose $(\triangle)$. Each data point represents the mean \pm SD of three separate experiments. 


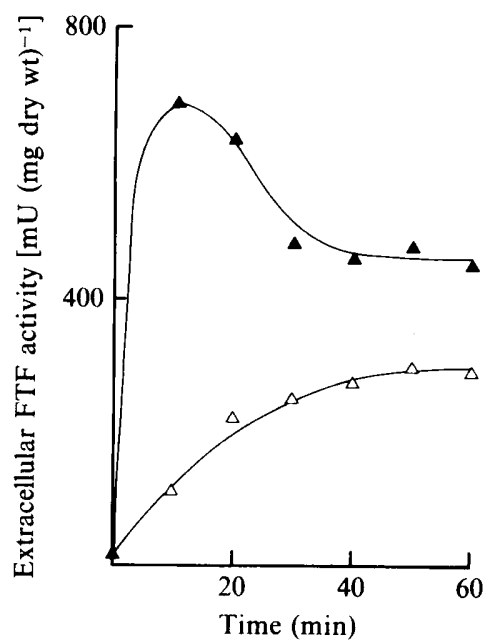

Fig. 3. Rapid release of the $\mathrm{Ca}^{2+}$-replete $(\boldsymbol{\Lambda})$ cell-bound FTF of $S$. salivarius ATCC 25975 in the presence of $5 \mathrm{~mm}$-sucrose compared with that of the $\mathrm{Ca}^{2+}$-depleted enzyme $(\triangle)$. Extracellular FTF activities were measured in the presence of $1 \mathrm{mM}-\mathrm{Ca}^{2+}$, for which the total (cellbound plus extracellular) $\mathrm{Ca}^{2+}$-replete and $\mathrm{Ca}^{2+}$-depleted FTF activities were $534 \mathrm{mU}\left(\mathrm{mg}\right.$ dry $\mathrm{wt}^{-1}$ and $484 \mathrm{mU}(\mathrm{mg} \text { dry wt })^{-1}$ respectively. In the absence of added $\mathrm{Ca}^{2+}$, the $\mathrm{Ca}^{2+}$-depleted FTF activity was $88 \mathrm{mU}(\mathrm{mg} \text { dry } \mathrm{wt})^{-1}$.

attempt to preferentially inactivate a putative factor involved in the release of cell-associated FTF activity. All were unsuccessful. $\mathrm{NaCl}$ within the range 0.5-1.5 M also failed to release any of the cell-bound FTF activity from $S$. salivarius ATCC 25975 whereas similar concentrations of $\mathrm{NaCl}$ have been reported to do so in $B$. subtilis strains 168 Marburg and QB112 (Chambert \& PetitGlatron, 1984).

The data that were amassed, however, suggested that fructan formation or substrate binding resulted in the release of the cell-bound FTF from $S$. salivarius ATCC 25975 . First, raffinose, a substrate polymerized by FTF enzymes, caused the release of cell-bound FTF in a concentration-dependent manner similar to sucrose (Fig. 2). Secondly, cells cycled through numerous generations by subculturing in $\mathrm{Ca}^{2+}$-deficient medium [and consequently possessing $\mathrm{Ca}^{2+}$-depleted FTF activity (Jacques, 1984)], released their cell-bound FTF activity in a slow and sustained manner in the presence of $5 \mathrm{~mm}$-sucrose. For instance, while with $\mathrm{Ca}^{2+}$-replete cells secretion of FTF was complete after $10 \mathrm{~min}, \mathrm{Ca}^{2+}$ depleted cells (possessing $20 \%$ of their maximum potential FTF activity in the absence of added $\mathrm{Ca}^{2+}$ ) had released only $23 \%$ of their FTF activity after the same time-period (Fig. 3).

In B. subtilis 168 Marburg and QB112, the cell-bound form of FTF has been reported to require $\mathrm{Fe}^{3+}$ for activity, whereas the secreted form does not (PetitGlatron et al., 1987). In the case of $S$. salivarius
ATCC 25975, the FTF activity released from $\mathrm{Ca}^{2+}$ depleted cells in the presence of $5 \mathrm{~mm}$-sucrose remained $\mathrm{Ca}^{2+}$-dependent. This was also the case for the extracellular FTF activity of $S$. salivarius ATCC 25975 purified from culture fluid by hydroxyapatite chromatography (L. J. Pitty \& N. A. Jacques, unpublished observations).

\section{Binding of glucosyltransferases to $S$. salivarius}

Unlike $S$. salivarius strain ATCC 25975 strains HB and MW15 produced little glucosyltransferase (GTF) activity when grown on a variety of carbohydrate sources including sucrose. By simply measuring GTF activity, no evidence was obtained for the induction of the enzyme by sucrose in any strain (data not shown). However, in the presence of sucrose, cells from all three strains were capable of binding the extracellular GTF activity produced by $S$. salivarius ATCC 25975 . (The mean percentage uptake of extracellular GTF $\left(300 \mathrm{mU} \mathrm{ml}^{-1}\right)$ following incubation of cells with sucrose was $69 \%, 89 \%$ and $87 \%$ for strains ATCC 25975, HB and MW15, respectively.) Growth in the presence of sucrose appeared to entrap FTF in the glucan matrix surrounding the cell (cf. Table 1). Despite this, the fructan formed by the entrapped enzyme was totally released into the extracellular environment (data not shown).

\section{Discussion}

The FTF activities of three strains of $S$. salivarius grown on glucose, fructose or galactose were shown to be $\mathrm{Ca}^{2+}$ dependent, with the majority of activity bound to the cells. In this respect the location of FTF activity in $S$. salivarius appears to be similar to that for the levansucrase (FTF) activity of $B$. subtilis 168 Marburg. Unfortunately, the nature of the cell-bound form in both genera is not clearly defined. While there is evidence that the cell-bound FTF of $S$. salivarius ATCC 25975 is dependent upon the lipid environment (Pitty \& Jacques, 1987), the suggestion that the levansucrase of $B$. subtilis 168 Marburg might be similarly attached to a lipidic anchor in the form of lipoteichoic acid (LTA) (Chambert \& Petit-Glatron, 1984) appears rather tenuous. This latter idea originated from the suggestion that the $s a c U$ locus might code for a deacylase and that the $\mathrm{Sac} \mathrm{U}^{\mathrm{h}}$ phenotype resulted from the overproduction of this deacylase and the release of the cell-bound levansucrase into the environment along with the deacylated LTA. However, recent evidence has shown that the sac $U$ locus codes for two proteins forming a sensor-transducer couple regulating the transcriptional apparatus (Kunst et al., 1988; Henner et al., 1988). Thus it is the increased rate of 
transcription of the $s a c B$ (levansucrase) gene in $s a c U^{\text {h }}$ strains accounts for the increased rate of expression of the levansucrase (Aymerich et al., 1986).

Differences in the nature of the enzymes from the two genera are, however, apparent. For instance, the $M_{\mathrm{r}}$ of the extracellular form produced by $B$. subtilis strains is 50000 (Petit-Glatron et al., 1987), whereas an $M_{\mathrm{r}}$ of approximately 140000 has been estimated for the extracellular form produced by S. salivarius ATCC 25975 (determined on SDS-PAGE; L. J. Pitty \& N. A. Jacques, unpublished observations). High-ionic-strength solutions such as $1.5 \mathrm{M}-\mathrm{NaCl}$ (this study) or $8 \mathrm{M}-\mathrm{LiCl}$ (Jacques \& Wittenberger, 1981) do not solubilize the cellbound form in $S$. salivarius ATCC 25975, whereas $1.5 \mathrm{M}-$ $\mathrm{NaCl}$ solubilizes the cell-associated form from $B$. subtilis strains. Both the cell-bound and extracellular FTF are $\mathrm{Ca}^{2+}$-dependent in $S$. salivarius whereas the cell-bound but not the extracellular levansucrase of $B$. subtilis requires $\mathrm{Fe}^{3+}$ for activity. In $B$. subtilis $\mathrm{Fe}^{3+}$ is considered to have a role in the refolding of the $M_{\mathrm{r}} 50000$ membrane-bound-form following the cleavage of a signal peptide, and it is this change in conformation that leads to the release of the enzyme from the cell (Chambert \& Petit-Glatron, 1988). In the case of $S$. salivarius ATCC 25975, sequence analysis of a recently cloned gene that codes for an FTF activity (Pitty et al., 1989) and comparison with the peptide sequences of the cell-bound and extracellular forms should give us further insight into the precursor/product relationships for FTF expression in this organism.

This work was supported by a Program Grant awarded by the Australian National Health and Medical Research Council.

\section{References}

Abbe, K., Takahashi-Abbe, S., Schoen, R. A. \& Wittenberger, C. L. (1986). Role of NADH oxidase in the oxidative inactivation of Streptococcus salivarius fructosyltransferase. Infection and Immunity 54, 233-238.
Aymerich, S., Gonzy-Treboul, G. \& Steinmetz, M. (1986). 5'Noncoding region $\operatorname{sacR}$ is the target of all identified regulation affecting the levansucrase gene in Bacillus subtilis. Journal of Bacteriology 166, 993-998.

Chambert, R. \& Petit-Glatron, M.-F. (1984). Hyperproduction of exocellular levansucrase by Bacillus subtilis: examination of the phenotype of a sac- $U^{\text {h }}$ strain. Journal of General Microbiology 130, 3143-3152.

Chambert, R. \& Petit-Glatron, M.-F. (1988). Secretion mechanism of Bacillus subtilis levansucrase: characterization of the second step. Journal of General Microbiology 134, 1205-1214.

HenNer, D. J., Yang, M. \& FerRarI, E. (1988). Localization of Bacillus subtilis sacU(Hy) mutations to two linked genes with similarities to the conserved procaryotic family of two-component signalling systems. Journal of Bacteriology 170, 5102-5109.

JACQUES, N. A. (1983). Membrane perturbation by cerulenin modulates glucosyltransferase secretion and acetate uptake by Streptococcus salivarius. Journal of General Microbiology 129, 3293-3302.

JACQUES, N. A. (1984). Calcium dependence of the cell-associated fructosyltransferase of Streptococcus salivarius. Carbohydrate Research 127, 349-355.

JACQUES, N. A. (1985). Inhibition of the expression of cell-associated fructosyltransferase in Streptococcus salivarius by octyl $\beta$-D-glucopyranoside. Journal of General Microbiology 131, 3243-3250.

JACQUES, N. A. \& WITTENBERGER, C. L. (1981). Inactivation of cellassociated fructosyltransferase in $S$. salivarius. Journal of Bacteriology 148, 912-918.

Kunst, F., Debarbouille, M., Msadek, T., Young, M., Mauel, C., Karamata, D., Klier, A., RAPOPORT, G. \& Dedonder, R. (1988). Deduced polypeptides encoded by the Bacillus subtilis sacU locus share homology with two-component sensor-regulator systems. Journal of Bacteriology 170, 5093-5101.

Markevics, L. J., KaH, K. K., Rathsam, L., Turner, L. W. \& JACQUES, N. A. (1987). Adaptation of the membrane fatty acid composition by growth in the presence of $n$-alkanols influences glycosyltransferase expression in Streptococcus salivarius. Journal of General Microbiology 133, 1543-1551.

Petit-Glatron, M.-F., Benyahia, F. \& Chambert, R. (1987). Secretion of Bacillus subtilis levansucrase: a possible two step mechanism. European Journal of Biochemistry 163, 379-387.

Pitty (née Markevics), L. J. \& JacQues, N. A. (1987). The influence of incorporation of octadecenoic acid on the cell-associated fructosyltransferase and the extracellular glucosyltransferase activities of Streptococcus salivarius. Journal of General Microbiology 133, 3565-3573.

PitTy, L. J., Giffard, P. M., Gilpin, M. L., Russell, R. R. B. \& JACQUES, N. A. (1989). Cloning and expression of glycosyltransferase activities from Streptococcus salivarius. Journal of Dental Research (in the Press).

WALKer, G. J. \& JACQUes, N. A. (1987). Polysaccharides of oral streptococci. In Sugar Transport and Metabolism in Gram-positive Bacteria, pp. 39-68. Edited by J. Reizer \& A. Peterkofsky. Chichester: Ellis Horwood. 